\title{
Scale Development of Taiwan Teacher's Sense of Organization Identification --From the Viewpoint of Workplace Spirituality
}

\author{
Wu Ho-Tang ${ }^{1}$, Chou Mei-Ju,"* \\ ${ }^{1}$ Department of Education, National Kaohsiung Normal University, Taiwan \\ ${ }^{2}$ Department of Early Childhood Education and Center for Teacher Education, National Pingtung University, Taiwan
}

Copyright (C) 2015 by authors, all rights reserved. Authors agree that this article remains permanently open access under the terms of the Creative Commons Attribution License 4.0 International License

\begin{abstract}
This study adopts workplace spirituality viewpoint to develop Teacher' Sense of Organizational Identification Scale. There are four procedures in process of developing the scale: 1. Literature analysis: In the past, people mainly developed Sense of Organizational Identification Scales by social identification theory or workplace spirituality. Sense of organization identification from scales of workplace spirituality is classified as the organization level, which content can be further divided as sense of goal connection, sense of identification with organization's values, and sense of organization care. Following literature analysis, draft of 18 items was proposed. 2. Reviewed by experts: After the initial draft of the 18 items were reviewed by four experts, one was deleted, one added, fourteen remaining the same, and three modified. 3. Exploratory Factor Analysis(EFA): The 18 items after reviewed by the experts were conducted $\operatorname{EFA}(N=235)$, and further divided into item analysis, factor analysis, and reliability analysis. In the first analysis, due to low loading of two items, we deleted them. After analyzed again, the reliability became acceptable. 4. Confirmatory Factor Analysis(CFA): We further investigated 332 teachers to confirm whether the Three Factor model's 16 items are stable. The result showed the initial model fits well. In addition, the initial model's basic fit does not "offends estimation," and the fit of the internal structure is acceptable(including the individual reliability, the composite reliability, the average variation extraction, and the construct discrimination analysis). Up to now, the Three Factor 16 items in the Teacher's Sense of Organizational Identification Scale was established, including sense of connection to organization's goal's(5 items), sense of connected to organization's goals(5 items), and sense of identification with organization's values(6 items). To conclude, the Sense of Organizational Identification Scale with three factor's 16 items has acceptable reliability for relative research.
\end{abstract}

Keywords Sense of Organizational Identification, Workplace Spirituality

\section{Introduction}

Organizational identification(OI) refers to a psychological linkage between the individual and the organization(Edwards \& Peccei, 2015)[1]. To make it even specifically, it refers to a kind of psychological connected status for the organizational goals, values, sense of belongingness, and attachment relationship(Edwards \& Peccei, 2007)[2]. Organizations have an important place in the life of an individual. People identify with their employing organization both at the cognitive and affective level, and enhance their self-esteem through this identification(Boroş, Curşeu, \& Miclea, 2015)[3]. Furthermore, Ashforth, Harrison and Corley(2008)[4] offer four reasons for the importance of OI. Firstly, it is an access for people to build the concepts of self-identity. Secondly, human beings have essential needs to identify with the group and the organization. Thirdly, OI is highly associated with employee satisfaction, performance and retention. Finally, interrelated links have been strongly made among OI, leadership, perceptions of justice, and the meaning of work. It could also advance work attitudes, motivation, job performance and satisfaction, individual decision making, and employee interaction and retention(Ashforth et al, 2008; Scott, Corman \& Cheney, 1998)[4] [5]. Therefore, the importance of sense of organizational identification for the employees is proved. As Valackiene(2015)[6] said, it is necessary to create the sense of identity of the members in the organization for its own objectives. However, in Taiwan, there is no research on teacher's sense of organizational identification due to a lack of teacher's sense of organizational identification scales. Therefore, it is necessary to develop such scales.

In foreign countries, a variety of sense of organizational identification scales have been developed based on social psychological theory, social identity theory, and 
self-categorization theory, and main theory is social identity theory(Christ, Van Dick, Wagner, \& Stellmacher, 2003)[7]. This theory involves that the self-concept is comprised of a personal identity, encompassing idiosyncratic characteristics such as abilities and interests, and a social identity, encompassing salient group classifications(Tajfel \& Turner, 2004)[8]. According on this theory, Mael \& Ashforth(1992)[9] edited Organizational Identification Scale which comprised of six items. In addition, Edwards \& Peccei(2007)[2] also presented a new six-item measure of OI that includes both cognitive and affective components and that integrates the main dimensions of $\mathrm{OI}$ found in the literature.

Besides, we discussed sense of organizational identification from the viewpoint of workplace spirituality, but one of the dimensions, the dimension of alignment between organizational and individual value in the Spirituality at Work Scale developed by Rego and e Cunha(2008) [10], Ashmos and Duchon(2000)[11] considered that workplace spirituality is a workplace where people experience joy and meaning in their work, a workplace in which people see themselves as part of a trusting community where they experience personal growth as a part of their work community, where they feel valued and supported would be a workplace in which spirituality thrives. Therefore, workplace spirituality oriented sense of organizational identification concentrates on raising spirituality, especially on connection between personal goals and organizational goals, the mission and values of the organization, and organizational care for the employees(Milliman, Czaplewski, \&Ferguson, 2003) [12], different from the social identity theory.

This research adopted teachers as the research subject, because Taiwanese elementary school, junior high school, and senior high school teachers' wage, work duration, and the retiring system are all protected by law, the job has high socio-economic status and high prestige, and teachers are instructors of both scripture and people; in short, it is a very meaningful job which makes our life full of meaning, and further leads to growth of spirituality. As a result, this scale used the viewpoint of workplace spirituality to develop Teacher's Sense of Organizational Identification Scale.

\section{Literature Discussion}

\section{(I) Workplace Spirituality}

Based on workplace spirituality, this research explained the content. Workplace spirituality is also called spirit at work, spirituality at work, spirituality in the workplace, organizational spirituality(Kinjerski, 2013) [13]. Workplace spirituality that focuses on the employees is an important trend in business in this century(Shellenbarger, 2000)[14]. Krishnakumar and Neck(2002)[15] mentioned that the reason why workplace spirituality attracts research is that people desire for experiencing spirituality increasingly not only in daily life but also at work. In addition, at work, spirituality can enhance commitment in the workplace(Krishnakumar \& Neck, 2002)[15], make people find harmony and values, and have them regard personal contribution of individual power to accomplishing the organizational goals as glory or meaning at work, sense of satisfaction, belongingness, completeness, and happiness(Garcia-Zamor, 2003) [16]. It can improve work satisfaction, work self-esteem, and job retention rate as well(Milliman et al, 2003)[12]. Moreover, the work environment will be more open and tolerant, and makes people patient, optimistic, concentrated, and stable(Heaton, Schmidt-Wilk, \& Travis, 2004)[17], the interpersonal relationship will be strengthened(Claude \& Zamor, 2003; Pielstick, 2005; Stevison, Dent, \& White, 2009) [18] [19] [20], and organizational efficacy will be raised(Jurkiewicz \& Giacalone, 2004)[21].

Regarding studies on workplace spirituality, there are many relative scales(see Table 1), and Ashmos and Duchon(2000)[11], and Milliman et al(2003)[12] considered that the dimensions can be classified into the individual level referring to sense of meaning, the group level referring to sense of community, and the organizational level-- the last one refers to sense of organizational identification in this research. Abdullah \& Ismail(2013) [22] indicated that the organization level in workplace spirituality is the practices that correlate with organizational values and exist at organizational stage. This dimension takes place when individual work experiences are able to be linked with individual values as it is, the mission and aim and purpose of the organization. In Table 1, what belongs to the organization level includes: "alignment with organizational values" in the scale of Milliman et al(2003)[12]; alignment between organizational and individual value in scale of Regoe and e Cunha(2008)[10]; coherent of organizational value dimension of scale of Abdullah \& Ismail(2013)[22]. Although the names are different, they all have the same content. In addition, Duchon \& Plowman's(2005) work unit community and work unit and meaningful work, Pawar(2009)[23] and Piryaei \& Zare's(2013)[24] positive organizational purpose are the same, because Pawar indicated that positive organizational purpose is measured through four items adapted from the "work unit community" and "work unit and meaningful work" subscales from Duchon and Plowman' scale. From Pawar's items of the two dimensions, it includes the three contents claimed by Milliman et al(2003)[12]: how the individual feels connected to organization's goals, how the individual identifies with organization's mission and values, and how organization cares about employees. Based on the three items as dimensions in sense of organizational identification, this research calls it sense of connected to organization's goals, sense of identification with organization's values, and sense of organization care, as described in the following Table. 
Table 1. Workplace spirituality scales

\begin{tabular}{|c|c|c|c|}
\hline Athor & Year & Scale & Dimension and title \\
\hline Milliman et al & $2003[12]$ & Workplace Spirituality Scale & $\begin{array}{l}\text { 1. Meaningful Work } \\
\text { 2. Sense of Community } \\
\text { 3. Alignment with Organizational Values } \\
\text { 1. Meaning at Work }\end{array}$ \\
\hline $\begin{array}{l}\text { Duchon and } \\
\text { Plowman }\end{array}$ & $2005[25]$ & $\begin{array}{c}\text { The Meaning and Purpose at Work } \\
\text { Questionnaire }\end{array}$ & $\begin{array}{l}\text { 2. Community } \\
\text { 3. Inner Life } \\
\text { 4. Work Unit Community } \\
\text { 5. Work Unit and Meaningful Work } \\
\text { 1. Team's sense of community }\end{array}$ \\
\hline Rego and e Cunha & $2008[10]$ & Spirituality at Work & $\begin{array}{l}\text { 2. Alignment between organizational and individual } \\
\text { value } \\
\text { 3. Sense of Contribution to the Community } \\
\text { 4. Sense of Enjoyment at Work } \\
1 \text { Meaning in Work }\end{array}$ \\
\hline Pawar & $2009[23]$ & Workplace Spirituality & $\begin{array}{l}\text { 2. Community at Work } \\
\text { 3. Positive Organizational Purpose }\end{array}$ \\
\hline Abdullah and Ismail & $2013[22]$ & Scale of Malay Version Workplace Spirituality & $\begin{array}{l}\text { 2. Community Sense Dimension } \\
\text { 3. Coherent of Organizational Value Dimension } \\
\text { 1. Meaningful Work }\end{array}$ \\
\hline Piryaei and Zare & $2013[24]$ & Workplace Spirituality & $\begin{array}{l}\text { 2. Sense of Community } \\
\text { 3. Positive Organizational Purpose }\end{array}$ \\
\hline
\end{tabular}

\section{(II). OI}

\section{A.Sense of Connection to Organization's Goals}

Organization's goals are important in guiding the individual, team, and organizational operation(Eby, Freeman, Rush, \& Lance, 1999)[26], and whether the organization's goals valued by the individual are also valued by the organization will influence on the degree he or she identify the organization(Wiener, 1982) [27], or his or her behaviors and attitudes towards the organization(Vancouver \& Schmitt, 1991)[28]. In addition, according to the viewpoint of organizational commitment, the more the members accept the organization's goals, the more they are willing to make efforts to support the organization and be the organization's members(Finegan, 2000)[29].

The so-called sense of connected to organization's goals is originated from Milliman et al's(2003) [12] "feeling connected to organization's goals, which can refer to Duchon and Plowman's(2005)[25] scale "work unit and meaningful work, and others such as: I feel connected with my immediate work unit's goals; and I feel connected with the mission of my immediate work unit. As for Abdullah \& Ismail's(2013)[22] Scale of Malay Version Workplace Spirituality, Coherent of Organizational Value Dimension can serve as reference as well: Connected with the aims of the school, and the school mission is my mission.

\section{B. Sense of Identification with Organization's Values}

Organizational values are one of the indicators for the organizational culture to take into considerations(Hofstede, Neuijen, Ohayv, \& Sanders, 1990)[30]. Organization supported theory suggests that, where employees perceive that the organization values and supports them, they will develop a greater psychological attachment to the
organization(Rhoades, Eisenberger, \& Armeli, 2001)[31].

So-called sense of identification with organization's value in this research is originated from Milliman et al's(2003) [12]so-called identifying with organization's mission and values, Duchon and Plowman's(2005)[25] scale's I feel positive about the values of my immediate work unit, and Milliman et al's Workplace Spirituality Scale's one item "organization's values are positive." Since they are not concrete and definite enough, less organization's values in relative scales can be consulted. Therefore, based on the content of values, we increased some questions.

\section{Sense of Organization Care}

Organization care is the deep-layer structure of organization's values that accomplishes the employees' need and fosters their best profit(Denison, 1996)[32]. The content includes caring the employees, taking care of the employees, and valuing the employees' contributions (McAllister \& Bigley, 2002)[33]. When the employees are respected and cared by their supervisors, they will be more assured that they are part of the organization, just like what Gardner and Pierce (1998) [34] called organization-based self-esteem (refers to the appropriateness and value to be the organization members).

The third dimension of sense of organizational identification in this research is sense of organization care originated from Milliman et al's(2003)[12] "organization cares about employees," and "work unit community" in scale of Duchon and Plowman(2005)[25], the items include the following items: my immediate work unit cares about whether my spirit is energized by my work; my immediate work unit encourages employees to develop new skills and abilities; my immediate work unit encourages the creation 
of community; my immediate work unit takes into account the responsibilities I have to my family; my immediate work unit is concerned about the poor in our community; and my immediate work unit cares about all its employees. As for Abdullah \& Ismail's(2013)[22] Scale of Malay Version Workplace Spirituality, coherent of organizational value dimension: the school cares towards staff who are facing problems; school takes care of the welfare of the workers. School understands teachers can be consulted as well.

\section{(III). Analysis of Related Scales of Sense of Organizational Identification}

There is no teacher's sense of organizational identification scales in Taiwan currently. In foreign areas, sense of organizational identification scales with teachers as the research subject include: Christ et al(2003)[7] developed Organisational Identification Scale, which adopted Social Identity Theory with a total of 21 items in three dimensions:(1) career identification: items such as "I identify myself with my professional career," and "I like to think about plans for my career";(2) team identification items such as "I identify myself with a certain team", "I like to work in my team"; and(3) identification with one's school items such as "I identify myself with the staff of my school", and "I feel not very comfortable in my present staff". In addition, Van Dick, Wagner, Stellmacher and Christ (2004)[35] developed for teachers the Organizational Identification Scale, including career(Seven items), team(eight items), school(seven items), occupational(seven items) and other identification items. Yildiz (2013)[36] also adopted the scale analysis of the relation of primary school teachers' OI and organizational communication. Such scales are based on social identity theory, emphasizing on identifying one's own job, coworkers, and group. However, from the viewpoint of workplace spirituality, this research concentrates on how the individual raises his or her own spirituality through connection with the organization's goals, identifying the organization's goals, and the organization's care for the employees and the society.

\section{Research Design}

\section{(I). Research Samples}

This research conducted, both with teachers under senior (vocational) high school teachers as the research subject through two web-based questionnaire surveys. On basis of the teachers known by the researcher, she emailed them the questionnaire, and asked them to forward it to others. By such way, the researcher collected data, which is called snow sampling. In order to avoid re-answering the questionnaire, the two surveys were proceeded through Google's Spreadsheet function, and the item of email address was required to answer to avoid repeated answerers. The second survey employed the written questionnaire by cluster sampling. The first samples were used on EFA, and the second ones on CFA. The two kinds of background allocations of the samples are listed in Table 2:

Table 2. The Sample Background Allocation

\begin{tabular}{|c|c|c|c|c|c|}
\hline & & \multicolumn{2}{|c|}{$\begin{array}{l}\text { EFA Samples } \\
(N=235)\end{array}$} & \multicolumn{2}{|c|}{$\begin{array}{c}\text { CFA Samples } \\
(N=332)\end{array}$} \\
\hline & & Times & Percentage & Times & Percentage \\
\hline \multirow{2}{*}{ Gender } & 1. Male & 60 & 25.5 & 113 & 34.0 \\
\hline & 2. Female & 174 & 74.0 & 218 & 65.7 \\
\hline \multirow{3}{*}{$\begin{array}{l}\text { School's educational } \\
\text { stage }\end{array}$} & 1. Elementary & 120 & 51.1 & 170 & 51.2 \\
\hline & 2. Junior high & 64 & 27.2 & 87 & 26.2 \\
\hline & 3. Senior high & 50 & 21.3 & 75 & 22.6 \\
\hline \multirow{2}{*}{ Marital status } & 1. Unmarried & 52 & 22.1 & 111 & 33.4 \\
\hline & 2. Married & 179 & 76.2 & 220 & 66.3 \\
\hline Length of service & & $M=16.82$ & $S D=7.64$ & $M=14.60$ & $S D=8.17$ \\
\hline
\end{tabular}

\section{(II). Data Process}

Regarding EFA: there were three tests on EFA: 1. Item analysis, including comparisons of extreme groups and correlation analysis. 2. Factor analysis: containing the test of co-variation, factor extraction and rotation shaft, and determination of factor number. 3. Reliability analysis: presented by Cronbach $\alpha$.

Regarding CFA: based on the EFA results, there are three factors in Sense of Organizational Identification--Connection to the Goals, Sense of Identification with Organization's Values, and Sense of Organization Care. By adopting first-order model and structural equation modeling(SEM) for verification, and analyzing with Amos 16.0 software, in regard of model fit indices, we used $\chi^{2}$, RMSEA, FGI, AGFl, NFI, RFI, IFI, TLI, and CFI to analyze the model's fit. For internal fit test, we adopted item quality, composite reliability $\left(\rho_{\mathrm{c}}\right)$, and average variance extracted $\left(\rho_{\mathrm{v}}\right)$, and construct discrimination for this test. 


\section{Results}

\section{(I) Results of Expert Validity}

The original draft of the 18 items was reviewed by the experts, and: one item was deleted: "my personal educational goal is consistent with the school's", because it is similar to "4. The personal and the school have the same educational prospect." One item was added, "7. Both the school and I hope our school is emerged with energy." 14 items remained the same, and 3 were modified, such as "6. The school and I do our best to develop the school's characteristics" was modified as the school and I make efforts to develop the school's characteristics. Lastly, since one item was added and one was deleted, the total number remains 18 .

Table 3. Code of the Items after Reviewed by the Experts

\begin{tabular}{|c|c|c|c|}
\hline Dimension & Item & Reviewed result & $\begin{array}{l}\text { EFA and } \\
\text { CFA code }\end{array}$ \\
\hline \multirow{8}{*}{$\begin{array}{l}\text { Sense of connection to } \\
\text { organization's goals(SCOG) }\end{array}$} & School supports me for further study & Remain the same & OI1 \\
\hline & $\begin{array}{l}\text { 2. I can make full use of my personal } \\
\text { strengths in school. }\end{array}$ & Remain the same & OI2 \\
\hline & The school's prospect is mine as well. & Remain the same & OI3 \\
\hline & $\begin{array}{l}\text { 4. My educational philosophy is } \\
\text { consistent with the school's }\end{array}$ & $\begin{array}{l}\text { Modified as: My educational philosophy is } \\
\text { consistent with the school's educational prospect }\end{array}$ & OI4 \\
\hline & $\begin{array}{l}\text { 5. The school and I have the same } \\
\text { educational goals. }\end{array}$ & $\begin{array}{l}\text { Deleted } \\
\text { (Similar to OI4) }\end{array}$ & \\
\hline & $\begin{array}{l}\text { 6. The school and I do our best to } \\
\text { develop the school's characteristics }\end{array}$ & $\begin{array}{l}\text { Modified as: The school and I make efforts o } \\
\text { develop the school's characteristics }\end{array}$ & OI5 \\
\hline & $\begin{array}{l}\text { 7. Both the school and I hope our school } \\
\text { is emerged with energy }\end{array}$ & Added & OI6 \\
\hline & The school's task is also mine. & Remain the same & OI7 \\
\hline \multirow[t]{5}{*}{$\begin{array}{l}\text { sense of identification with } \\
\text { organization's values(SIOV) }\end{array}$} & $\begin{array}{l}\text { 9. Both school and I value social } \\
\text { responsibility }\end{array}$ & Remain the same & OI8 \\
\hline & $\begin{array}{l}\text { 10. School and I emphasize on the } \\
\text { scientific working attitude of seeking } \\
\text { the truth. }\end{array}$ & Remain the same & OI9 \\
\hline & $\begin{array}{l}\text { Both school and I value integrity } \\
\text { and honesty }\end{array}$ & Remain the same & OI10 \\
\hline & 11. Both school and I value performance & $\begin{array}{l}\text { Modified as: Both school and I value teaching(or } \\
\text { administrative) performance }\end{array}$ & OI11 \\
\hline & 12. Both school and I value team spirit & Remain the same & OI12 \\
\hline \multirow{6}{*}{$\begin{array}{l}\text { Sense of organization } \\
\text { care)(SOC) }\end{array}$} & 13. School respects my personal feelings & Remain the same & OI13 \\
\hline & $\begin{array}{l}\text { 14. School cares the teachers' health } \\
\text { condition }\end{array}$ & Remain the same & OI14 \\
\hline & $\begin{array}{l}\text { 15. School cares teacher who has } \\
\text { accidental event in his or her family }\end{array}$ & Remain the same & OI15 \\
\hline & 16. School cares the teachers' welfare & Remain the same & OI16 \\
\hline & $\begin{array}{l}\text { 17. School can understand the situation } \\
\text { when I cannot balance work and } \\
\text { family }\end{array}$ & Remain the same & OI17 \\
\hline & $\begin{array}{l}\text { 18. School cares and mentors the } \\
\text { unqualified teachers }\end{array}$ & Remain the same & OI18 \\
\hline
\end{tabular}

\section{(II). EFA Analysis}

After reviewed by the experts, the 18 items were edited as the pretest questionnaire, a five-point Likert format with responses ranging from 1 (strongly disagree) to 5 (strongly agree). From literature analysis, we found that there are fewer items regarding workplace spirituality dimension in sense of organizational identification, so we increased the items. To confirm whether the items would aggregate on the designed ones, we adopted EFA for factor exploration first, and the steps are as follows:

\section{A. Item Analysis}

On comparisons of extreme groups, we summed up the returned pretest questionnaires $(N=235)$ : the first $27 \%$ of the total score was called the high-score $\operatorname{group}(n=69)$, the last $27 \%$ of the total score was called the low-score $\operatorname{group}(n=$ 65). The independent sample $t$ test results(see Table 4 ) are: $t$ value ranges between $.45-15.85$, all the critical ratios are 
over 3, and achieve the significant standard, signifying that the 18 items possess the discriminative power.

On correlation coefficient analysis, the results show that $r$ value of all items and the total score ranges between .63-.83, and all achieve significant $\operatorname{standard}(p<.001)$, indicating that the items and the dimension is highly correlative, which means the same concept can be measured(McLever \& Carmines, 1981)[37].

\section{B. Factor Analysis}

The item analysis results are fit, so we further conducted factor analysis for the 18 items. Data were analysed using Principal Axis factoring with oblique rotation's promax method. On the initial factor analysis, the Kaiser-Meyer-Olkin(KMO) measure of sampling adequacy was .95 and the Barlett's Test of Sphericity $\chi^{2}=2855.23$, $p<.001$, indicating that the data were suitable for factor analysis.

On determining the number of factors, Kaiser(1960)[38] proposed that the eigenvalue is more than 1 to determine retention of the factor's number, but it is easy for overestimation or underestimation of the factor's number(Fabrigar, Wegener, MacCallum \& Strahan, 1999)[39]. On the other hand, the scree plot proposed by Cattell(1966)[40] is too subjective, while Horn's(1965)[41] parallel analysis can estimate the factor's number more precisely. The results are: there are three factors' eigenvalue $>1,9.11,1.49$, and 1.01 ; factors after the fourth one are almost on the same line, meaning that it is proper to extract the fourth factor. As for parallel analysis, the results suggested to adopt three dimensions, as our literature analysis did, so we decided three.

The first factor analysis was then proceeded, and the first factor found in the sample matrix are $\operatorname{OI} 1(\lambda=.37)$, OI13( $\lambda=.63), \quad$ OI14 $(\lambda=.84), \quad$ OI15( $\lambda=.83), \quad$ OI16 $(\lambda=.79)$, OI17 $(\lambda=.86)$, OI18 $(\lambda=.63)$; the second factor are composed by $\operatorname{OI} 6(\lambda=.47), \operatorname{OI} 8(\lambda=.69), \operatorname{OI} 9(\lambda=.75), \operatorname{OI} 10(\lambda=.88)$, $\operatorname{OI1}(\lambda=.65)$, and $\operatorname{OI} 12(\lambda=.74)$; and the third factor are composed by $\mathrm{OI} 2(\lambda=.57), \quad \mathrm{OI} 3(\lambda=.93), \quad \mathrm{OI} 4(\lambda=.78)$, $\operatorname{OI} 5(\lambda=.59)$, and $\operatorname{OI} 7(\lambda=.59)$. Basically, most comply the items planned according to the literature. Tabachnica and Fidell(2007)[42] considered when $\lambda \geqq .55$, it can be called good. Based on this standard, OI1 $(\lambda=.37)$ and $\operatorname{OI} 6(\lambda=.47)$ do not meet the standard, so we deleted these two items.

After deleting OI1 and 6, we conducted the second EFA(see Table 5). The second EFA results are consistent with the original design, among which the explained variance of the first factor sense of organization care is $52.33 \%$, that of the second factor(sense of identification with the organization's values is $7.43 \%$, and the third factor(sense of connected to organization's goals) is $4.37 \%$, with the total variance at $64.13 \%$.

In short, the second EFA, the aggregated items completely comply with the literature, and the pattern coefficient ranges between .59-.89.

Table 4. Summary of Item Analysis

\begin{tabular}{|c|c|c|c|c|}
\hline Item & $t$ & Result & $r$ & $\begin{array}{c}\text { Correlation analysis } \\
\text { results }\end{array}$ \\
\hline OI1 & $10.05 * * *$ & Remain & $.64 * * *$ & Remain \\
\hline OI2 & $8.50 * * *$ & Remain & $.63 * * *$ & Remain \\
\hline $\mathrm{OI} 3$ & $13.11 * * *$ & Remain & $.77 * * *$ & Remain \\
\hline OI4 & $14.98^{* * *}$ & Remain & $.81 * * *$ & Remain \\
\hline OI5 & $14.02 * * *$ & Remain & $.80 * * *$ & Remain \\
\hline OI6 & $8.45^{* * *}$ & Remain & $.67 * * *$ & Remain \\
\hline OI7 & $14.08 * * *$ & Remain & $.81 * * *$ & Remain \\
\hline OI8 & $13.35^{* * *}$ & Remain & $.79 * * *$ & Remain \\
\hline OI9 & $12.74 * * *$ & Remain & $.80^{* * *}$ & Remain \\
\hline OI10 & $12.35 * * *$ & Remain & $.78 * * *$ & Remain \\
\hline OI11 & $11.23^{* * *}$ & Remain & $.71 * * *$ & Remain \\
\hline OI12 & $13.67 * * *$ & Remain & $.82 * * *$ & Remain \\
\hline OI13 & $14.37 * * *$ & Remain & $.80^{* * *}$ & Remain \\
\hline OI14 & $15.85^{* * *}$ & Remain & $.83^{* * *}$ & Remain \\
\hline OI15 & $13.24 * * *$ & Remain & $.76^{* * *}$ & Remain \\
\hline OI16 & $12.91 * * *$ & Remain & $.77 * * *$ & Remain \\
\hline OI17 & $12.56 * * *$ & Remain & $.75 * * *$ & Remain \\
\hline OI18 & $11.79^{* * *}$ & Remain & $.77 * * *$ & Remain \\
\hline
\end{tabular}

$* * * p<.001$. 
Table 5. The Second EFA

\begin{tabular}{|c|c|c|c|c|c|c|c|c|c|c|}
\hline \multirow{2}{*}{ Factor Name } & \multirow{2}{*}{ Item } & \multicolumn{3}{|c|}{ Pattern coefficient } & \multicolumn{3}{|c|}{ Structure coefficient } & \multirow{2}{*}{ Communality } & \multirow{2}{*}{$\begin{array}{c}\text { Explained } \\
\text { Variance(\%) }\end{array}$} & \multirow{2}{*}{ Reliability } \\
\hline & & 1 & 2 & 3 & 1 & 2 & 3 & & & \\
\hline \multirow[t]{5}{*}{ SCOG } & OI2 & 0.09 & -0.11 & 0.59 & 0.38 & 0.38 & 0.57 & 0.33 & 4.37 & .88 \\
\hline & OI3 & -0.03 & -0.04 & 0.94 & 0.52 & 0.61 & 0.89 & 0.79 & & \\
\hline & OI4 & 0.03 & 0.11 & 0.78 & 0.58 & 0.69 & 0.88 & 0.77 & & \\
\hline & OI5 & -0.09 & 0.36 & 0.59 & 0.52 & 0.72 & 0.79 & 0.68 & & \\
\hline & OI7 & 0.14 & 0.16 & 0.59 & 0.61 & 0.68 & 0.79 & 0.67 & & \\
\hline \multirow[t]{5}{*}{ SIOV } & OI8 & 0.10 & 0.66 & 0.10 & 0.60 & 0.79 & 0.63 & 0.64 & 7.43 & .89 \\
\hline & OI9 & -0.03 & 0.80 & 0.09 & 0.56 & 0.84 & 0.64 & 0.70 & & \\
\hline & OI10 & 0.03 & 0.87 & -0.10 & 0.55 & 0.81 & 0.54 & 0.66 & & \\
\hline & OI11 & -0.08 & 0.64 & 0.11 & 0.42 & 0.66 & 0.52 & 0.45 & & \\
\hline & OI12 & 0.16 & 0.73 & -0.05 & 0.62 & 0.80 & 0.57 & 0.65 & & \\
\hline \multirow[t]{6}{*}{$\mathrm{SOC}$} & OI13 & 0.62 & 0.07 & 0.14 & 0.75 & 0.59 & 0.57 & 0.58 & 52.33 & .91 \\
\hline & OI14 & 0.84 & 0.13 & -0.07 & 0.89 & 0.65 & 0.54 & 0.79 & & \\
\hline & OI15 & 0.83 & 0.13 & -0.15 & 0.82 & 0.58 & 0.46 & 0.69 & & \\
\hline & OI16 & 0.79 & -0.11 & 0.14 & 0.81 & 0.53 & 0.55 & 0.66 & & \\
\hline & OI17 & 0.84 & -0.19 & 0.12 & 0.79 & 0.47 & 0.51 & 0.64 & & \\
\hline & OI18 & 0.64 & 0.16 & -0.01 & 0.74 & 0.58 & 0.49 & 0.55 & & \\
\hline \multicolumn{9}{|c|}{$\begin{array}{l}\text { Total Explained Variance and total } \\
\text { reliability }\end{array}$} & 64.13 & .94 \\
\hline
\end{tabular}

Note: Factor loading $>.55$ are in boldface.

\section{Reliability Analysis}

We carried out reliability analysis for the remaining 16 items in the second factor analysis, and the results show Cronbach's $\alpha$ of SCOG, SIOV, and SOC are .88, .89, and .91, and the total reliability is .94 . That is, regardless of dimension or overall, it meets the standard of $>.80$, signifying that the items have stability.

\section{(III). CFA Analysis}

\section{A. Correlation Coefficient of the Three Latent Variables in Sense of Organizational Identification Scale}

Table 6. Correlation Coefficient of the Three Latent Variables in Sense of Organizational Identification and Descriptive Data

\begin{tabular}{cccccc}
\hline Item and Code & 1 & 2 & 3 & $M$ & $S D$ \\
\hline SCOG & 1 & & & 17.59 & 3.55 \\
SIOV & $.79 * * *$ & 1 & & 18.78 & 3.46 \\
SOC & $.69 * * *$ & $.72 * * *$ & 1 & 20.60 & 4.93 \\
\hline
\end{tabular}

$* * * p<.001$.
We adopted the remaining $16 \mathrm{~s}$ in EFA analysis to investigate 332 teachers, and summed up the dimension of sense of organizational identification and the total score for correlation coefficient, and the results show that the correlation coefficient ranges between .69-.79.

\section{B. The Initial Model of CFA}

The 16 items of the three factors reviewed by the experts are classified as the initial model, which was then verified with CFA. After confirming by the correlation coefficient that there is significantly positive correlation between the three latent variables and the total score, we then conducted CFA(see Fig. 1): regarding the overall fit of the initial model: $\chi^{2}=280.79, d f=101, p=.00$, RMSEA $=.07$, GFI $=.91$, $\mathrm{AGFI}=.87, \mathrm{NFI}=.94, \mathrm{RFI}=.93, \mathrm{IFI}=.96, \mathrm{TLI}=.95, \mathrm{CFI}$ $=.96$, and $\chi^{2}$ achieves significant standard, not meeting the standard. Since $\chi^{2}$ tends to be influenced by sample number easily, the value is just for consultancy. AGFI does not meet the standard of .90, yet Anderson and Gerbing(1984)[43] claimed that AGFI $\geq 0.80$ is ok. Therefore, most fit indices meet the standard, so the initial model is acceptable. 


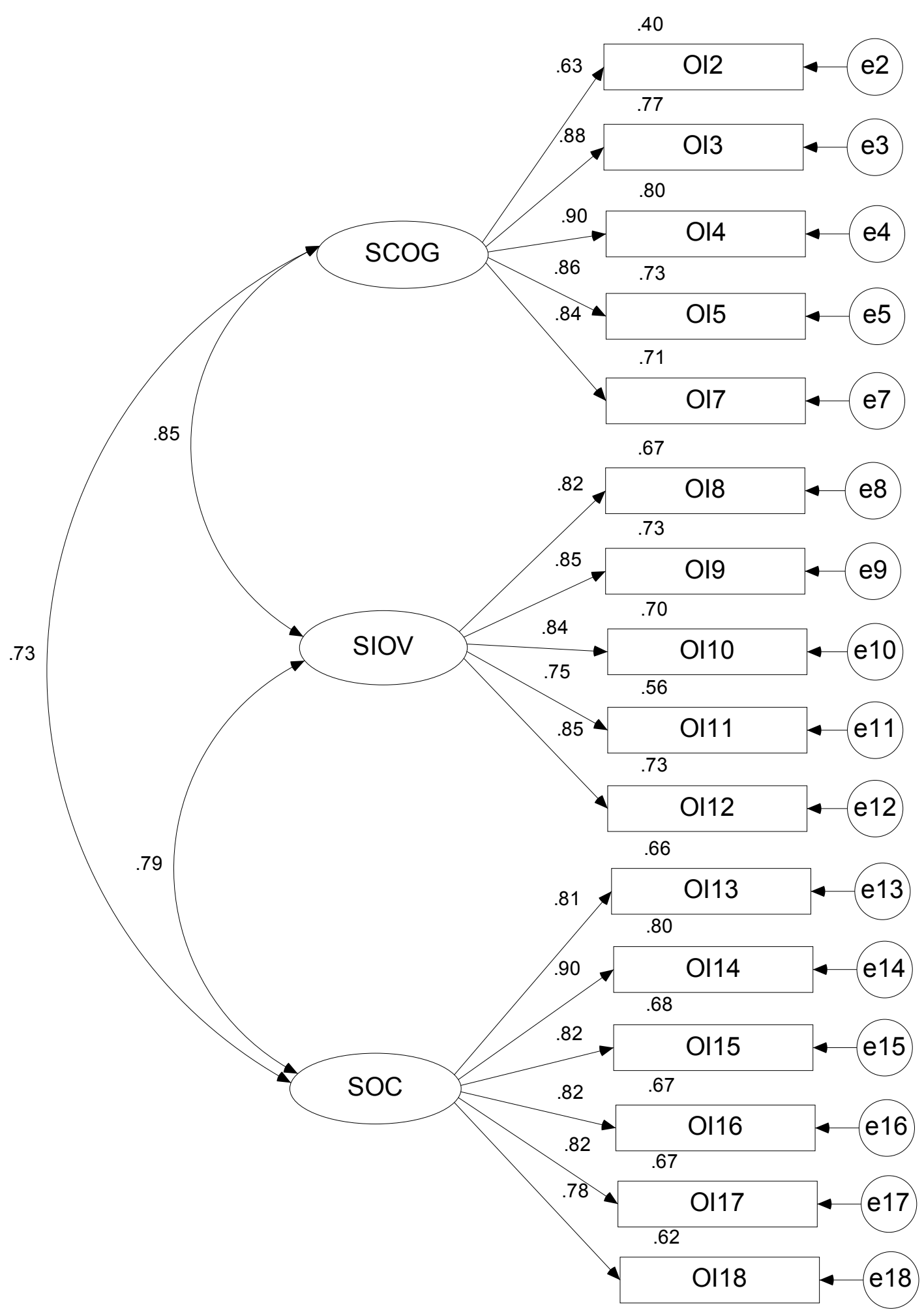

Note: Data on the indices are individual reliability

Figure 1. Goodness-of-fit of modified model (Standardized estimates) 


\section{Preliminary Fit}

After analyzing preliminary fit(Table 7): 1 . in $\Theta_{\varepsilon}$ matrix entries, the error variance from $\varepsilon_{1-} \varepsilon_{18}$ are all positive. 2. All error variances' $t$ value ranges between 9.29-12.29, and all achieves the significant standard of $>.01$. 3. The standard error ranges between $.01-.12$, not very large. 4 . The factor loading $\left(\lambda_{1}-\lambda_{18}\right)$ latent variables and the indicators) is between .63-.90, meeting the standard of $>.50$ and $<.95$. Based on the analysis above, the results all meet the standard, meaning that the item quality is good without offending estimates(refers to the output data do not exceed the acceptable range)(Hair, Anderson, Tatham, \&Black, 1998)[44].

Table 7. Summary of Parameter Estimation of the Initial Model

\begin{tabular}{|c|c|c|c|c|c|c|c|c|c|c|c|}
\hline & & Parameter & & $\begin{array}{l}\text { Un-standardized } \\
\text { estimated value }\end{array}$ & $\begin{array}{l}\text { Standard } \\
\text { error }\end{array}$ & $t$ & $p$ & $\begin{array}{l}\text { Standardized } \\
\text { estimated } \\
\text { value(factor } \\
\text { loading) }\end{array}$ & $\begin{array}{l}\text { Indicators" } \\
\text { individual } \\
\text { reliability }\end{array}$ & $\begin{array}{c}\text { Average } \\
\text { variance } \\
\text { extraction }\end{array}$ & $\begin{array}{c}\text { Latent } \\
\text { variable's } \\
\text { composite } \\
\text { reliability } \\
\end{array}$ \\
\hline SCOG & $\leftarrow$ & SIOV & $\Phi_{1}$ & 0.27 & 0.03 & 8.48 & $* * *$ & & & & \\
\hline SCOG & $\leftarrow$ & SOC & $\Phi_{2}$ & 0.27 & 0.03 & 7.99 & $* * *$ & & & & \\
\hline SIOV & $\leftarrow$ & SOC & $\Phi_{3}$ & 0.38 & 0.04 & 9.27 & $* * *$ & & & & \\
\hline OI2 & $\leftarrow$ & SCOG & $\left(\lambda_{2}\right)$ & 1.00 & & & & 0.63 & 0.40 & 0.69 & 0.91 \\
\hline $\mathrm{OI} 3$ & $\leftarrow$ & SCOG & $\left(\lambda_{3}\right)$ & 1.54 & 0.12 & 13.15 & $* * *$ & 0.88 & 0.77 & & \\
\hline OI4 & $\leftarrow$ & SCOG & $(\lambda 4)$ & 1.42 & 0.11 & 13.29 & $* * *$ & 0.90 & 0.80 & & \\
\hline OI5 & $\leftarrow$ & SCOG & $\left(\lambda_{5}\right)$ & 1.54 & 0.12 & 12.89 & $* * *$ & 0.86 & 0.73 & & \\
\hline OI7 & $\leftarrow$ & SCOG & $\left(\lambda_{7}\right)$ & 1.41 & 0.11 & 12.64 & $* * *$ & 0.84 & 0.71 & & \\
\hline OI8 & $\leftarrow$ & SIOV & $\left(\lambda_{8}\right)$ & 1.00 & & & & 0.82 & 0.67 & 0.68 & 0.91 \\
\hline OI9 & $\leftarrow$ & SIOV & $\left(\lambda_{9}\right)$ & 1.08 & 0.06 & 18.59 & $* * *$ & 0.85 & 0.73 & & \\
\hline OI10 & $\leftarrow$ & SIOV & $\left(\lambda_{10}\right)$ & 1.10 & 0.06 & 18.01 & $* * *$ & 0.84 & 0.70 & & \\
\hline OI11 & $\leftarrow$ & SIOV & $\left(\lambda_{11}\right)$ & 0.91 & 0.06 & 15.24 & $* * *$ & 0.75 & 0.56 & & \\
\hline $\mathrm{OI} 12$ & $\leftarrow$ & SIOV & $\left(\lambda_{12}\right)$ & 1.11 & 0.06 & 18.26 & $* * *$ & 0.85 & 0.73 & & \\
\hline OI13 & $\leftarrow$ & SOC & $\left(\lambda_{13}\right)$ & 1.00 & & & & 0.82 & 0.66 & 0.69 & 0.93 \\
\hline OI14 & $\leftarrow$ & SOC & $\left(\lambda_{14}\right)$ & 1.17 & 0.06 & 20.05 & $* * *$ & 0.90 & 0.80 & & \\
\hline OI15 & $\leftarrow$ & SOC & $\left(\lambda_{15}\right)$ & 1.00 & 0.06 & 17.44 & $* * *$ & 0.82 & 0.68 & & \\
\hline OI16 & $\leftarrow$ & SOC & $\left(\lambda_{16}\right)$ & 1.02 & 0.06 & 17.31 & $* * *$ & 0.82 & 0.67 & & \\
\hline OI17 & $\leftarrow$ & SOC & $\left(\lambda_{17}\right)$ & 1.01 & 0.06 & 17.46 & $* * *$ & 0.82 & 0.67 & & \\
\hline OI18 & $\leftarrow$ & SOC & $\left(\lambda_{18}\right)$ & 1.09 & 0.07 & 16.37 & $* * *$ & 0.79 & 0.62 & & \\
\hline e2 & & & $\left(\varepsilon_{2}\right)$ & 0.36 & 0.03 & 12.29 & $* * *$ & & & & \\
\hline e3 & & & $\left(\varepsilon_{3}\right)$ & 0.18 & 0.02 & 9.82 & $* * *$ & & & & \\
\hline e4 & & & $\left(\varepsilon_{4}\right)$ & 0.12 & 0.01 & 9.22 & $* * *$ & & & & \\
\hline e5 & & & $\left(\varepsilon_{5}\right)$ & 0.21 & 0.02 & 10.39 & $* * *$ & & & & \\
\hline e7 & & & $\left(\varepsilon_{7}\right)$ & 0.20 & 0.02 & 10.66 & $* * *$ & & & & \\
\hline e8 & & & $\left(\varepsilon_{8}\right)$ & 0.20 & 0.02 & 10.89 & $* * *$ & & & & \\
\hline e9 & & & $\left(\varepsilon_{9}\right)$ & 0.18 & 0.02 & 10.29 & $* * *$ & & & & \\
\hline e10 & & & $\left(\varepsilon_{10}\right)$ & 0.21 & 0.02 & 10.58 & $* * *$ & & & & \\
\hline e11 & & & $\left(\varepsilon_{11}\right)$ & 0.26 & 0.02 & 11.62 & $* * *$ & & & & \\
\hline e12 & & & $\left(\varepsilon_{12}\right)$ & 0.19 & 0.02 & 10.16 & $* * *$ & & & & \\
\hline e13 & & & $\left(\varepsilon_{13}\right)$ & 0.29 & 0.03 & 11.13 & $* * *$ & & & & \\
\hline e14 & & & $\left(\varepsilon_{14}\right)$ & 0.19 & 0.02 & 9.29 & $* * *$ & & & & \\
\hline e15 & & & $\left(\varepsilon_{15}\right)$ & 0.27 & 0.03 & 11.03 & $* * *$ & & & & \\
\hline e16 & & & $\left(\varepsilon_{16}\right)$ & 0.29 & 0.03 & 11.01 & $* * *$ & & & & \\
\hline e17 & & & $\left(\varepsilon_{17}\right)$ & 0.29 & 0.03 & 11.11 & $* * *$ & & & & \\
\hline $\mathrm{e} 18$ & & & $\left(\varepsilon_{18}\right)$ & 0.42 & 0.04 & 11.46 & $* * *$ & & & & \\
\hline
\end{tabular}


Table 8. Summary of Construct Discrimination in Sense of Organizational Identification Analysis

\begin{tabular}{cccccccccc}
\hline & \multicolumn{3}{c}{ Restrictive model(B) } & \multicolumn{3}{c}{ Nonrestrictive model(A) } & \multicolumn{2}{c}{$\begin{array}{c}\chi^{2} \\
\text { difference(B-A) }\end{array}$} \\
\cline { 2 - 9 } Latent variable & $\rho_{1}$ & $d f$ & $\chi^{2}$ & $\rho$ & $d f$ & $\chi^{2}$ & $\Delta \chi^{2}$ \\
\hline SCOG-SIOV & 1 & 35 & 251.86 & .89 & 34 & 148.34 & $103.52^{*}$ \\
SIOV-SOC & 1 & 44 & 209.13 & .79 & 43 & 129.35 & $79.78^{*}$ & $113.47^{*}$ \\
SCOG-SOC & 1 & 44 & 242.56 & .73 & 43 & 129.09 & \\
\hline
\end{tabular}

Note:* refers to the restrictive model's and the nonrestrictive model's Chi-square difference are both $>3.84$, reaching the significant standard of .05 .

\section{Analysis of the Internal Structural Fit}

Regarding individual reliability, the individual reliability of the 16 indicator ranges between .40-.80. Bollen(1989)[45] pointed out that the latent variable's individual indicator must has fair reliability, or the model cannot be supported. Bagozzi and Yi(1988)[46] indicated that the individual reliability(square of factor loading) should be larger than .50; that is, the individual factor loading should be larger than .71 in order to reflect the extent of the latent variable. As Hair et al(1998)[44] considered high factor loading means the items have good convergent validity.

In regard of composite reliability, the three latent variables are $\mathrm{SCOG}=.91, \mathrm{SIOV}=.91$, and $\mathrm{SOC}=.93$, respectively, all meeting the standard of $>.60$, and signifying that all can measure $91 \%$ or more of the latent construct. In other words, the three latent variables have preliminary stability in reflecting the real score.

In regard of the average variance extraction, the three latent variables are $\mathrm{SCOG}=.69, \mathrm{SIOV}=.68$, and $\mathrm{SOC}=.69$, respectively, all meeting the standard of $>.50$. That is to say, the three latent variables can be effectively estimated their convergent indicators by the group's indicators(Fornell \& Larcker, 1981)[47].

In regard of construct discrimination, this research adopted competing models(Anderson \& Gerbing, 1988)[48] to inspect the latent variables' construct discrimination: the Chi-square variance $\left(\Delta \chi^{2}\right)$ between the restrictive models and nonrestrictive models are 103.52, 79.78 , and 113.47 , respectively, all meeting the significant standard of .05, and all larger than the threshold value 3.84( $p$ $<.05$ )(see Table 8), meaning that there is significant difference between the latent traits. Therefore, the hypothesis that correlation between any two paired latent variables is complete correlation fails, meaning that the three latent variable in the scale are significantly different.

According to the analysis above, as a whole, the internal structure of the initial model is fit, meaning that the variables can reflect the constructed latent variables.

\section{General Discussion}

The purpose of this research is to develop the Teacher's Sense of Organizational Identification Scale, and the process involves reading relative literature, the viewpoint of Milliman et al(2003)[12], to classify sense of organizational identification into sense of connection to the organization's goals, sense of identification with organization's values, and sense of organization care. In addition, while editing the initial draft, we also consulted the relative Workplace Spirituality Scales. In this stage, the draft of Teacher's Sense of Organizational Identification Scale with 18 items was output.

Next, four experts were invited to review the draft of Teacher's Sense of Organizational Identification Scale: one item was deleted due to similarity in two s, one was added, 14 remained the same, and three were modified-- at last, the total number of the items remains 18, unchanged. The purpose of review by the experts is to provide theoretical and practical opinions for modification, so that the questionnaire can be even closer to the realistic and practical educational site.

Thirdly, the 18 items of the three dimensions after reviewed by the experts were conducted EFA analysis in three steps: 1. Item analysis: the results show the 18 items' determination value and correlation coefficient meet the standard both, presenting discrimination power. 2. Factor analysis: two items were deleted in the first analysis due to lower factor loading-- one of them is OI1: "School supports me for further study". Presently, the educational administration units in Taiwan regulates the teacher's further study hour in each semester; for example, the second large city in Taiwan, Kaohsiung City, regulates that teacher has to further study at least 18 hours in each semester. In other word, teacher's further study has become a normal status in Taiwan with no need to support it particularly. The other deleted item is OI6, "School and I hope the school is full of energy," which may relates to stress of working load. Huang(2015)[49] adopted mata-analysis to analyze 68 studies on Taiwanese teachers' work stress. The results show that the effect size of stress of working load is $.59(p<.001)$. According to the standard of Cohen(2013)[50], it is moderate degree, meaning that the teachers indeed have work pressures, which cause sense of fatigue(Byrne, 1994; Friedman,1995)[51] [52]. After deleting the 2 items, we further conducted the second factor analysis, and the results show the factors are as planned and have acceptable reliability and validity.

Fourthly, we verified the stability of the three factors' 16 items obtained from EFA, and found that the overall fit is acceptable, the preliminary fit is good, and the internal structure's fit is fair. To conclude, the CFA results are consistent with EFA results. Up to now, the three factors' 16 items in the Teacher's Sense of Organizational Identification 
Scale is stable. The 16 items are 5 in dimension of sense of connected to organization's goals, 5 in dimension of sense of identification with organization's values, and 6 in dimension of sense of organization care. The number meet what claimed by Bollen(1989)[45] that the optimal number is each factor is around 5-7.

For the analysis above, regardless of EFA or CFA, the scale developed in this research has acceptable reliability and validity. Besides, there are totally 16 items divided into three dimensions, more than the Organizational Identification Scale which was developed by Mael \& Ashforth(1992)[9] on basis of this theory. Although Riketta(2005) [53] considered that this scale is narrower and more distinct from the affective organizational commitment, but more useful when examining or predicting employee extra role behavior and job involvement, but there are only 6 items in this scale: 1 . When someone criticizes(name of school), it feels like a personal insult. 2. I am very interested in what others think about(name of school). 3. When I talk about this school, I usually say 'we' rather than 'they'. 4. This school's successes are my successes. 5 . When someone praises this school, it feels like a personal compliment. 6 . If a story in the media criticized the school, I would feel embarrassed. On the other hand, this scale merely uses the total score without categorized dimensions. Furthermore, our scale's items are also more than Edwards \& Peccei's(2007)[1], which presents a new six-item measure of OI that includes both cognitive and affective components and that integrates the main dimensions of OI found in the literature. The new measure comprises three main subcomponents: Self-categorization and labeling(Items: 1. My employment in the organization is a big part of who I am. 2. I consider myself an organization person.), Sharing organizational goals and values(Items: 3. What the organization stands for is important to me. 4. I share the goals and values of the organization.), Sense of attachment, belonging, and membership of the organization(Items: 5. My membership of the organization is important to me. 6. I feel strong ties with the organization.). This scale attempts to involve three dimensions, but each has only two items. In Bollen's(1989)[45] viewpoint, each dimension must has at least 3 items. Besides, due to low discriminant validity, the author himself proposed a single overall measure of OI.

In foreign areas, sense of identification with the organization scales developed with subject of the teachers include Christ et al's(2003)[7] Organisational Identification according to Social Identity Theory with 21 items in 3 dimensions(identification with career, team, and school), and Van Dick's(2004)[37] Teacher's Organizational Identification Scale with 29 items in dimension of career, team, school, and occupational identification. Such scales are all developed on the foundation of social identity theory, emphasizing on identifying one's own career, coworkers, and group. For this research, from viewpoint of workplace spirituality, we have developed a scale that values identification with the organization's goals, values, and care for both the employees and the society.

\section{Implications and Limitation}

\section{(I).Teacher' Sense of Organizational Identification Scale}

There are three dimensions and 16 items in this scale. The number of items is fair, since in Taiwan, there are a lot of graduate schools as well as studies with teachers as the subject, many teachers withdrew upon seeing the questionnaire. There were only 16 items in this research, so it could raise teachers' willingness to answer.

In addition, since Teachers' Act was announced in 1995, school can establish School Teachers' Association by law, so in regard of school power, it demonstrate an administration-teacher-parents power distribution situation. Under such circumstance, teacher's identification for school has become incomparable to that in the past, so this scale can function as the research tool of study on teachers' sense of identification with organization.

Moreover, this scale can be utilized to conduct relative research. According to the western research results, Edwards \& Peccei(2015)[1] show that OI positively correlates with organizational support and trust involvement significantly, and negatively correlates with trust intention to leave. Avanzi, Schuh, Fraccaroli and Van Dick (2015)[54] also found that strong identification with their organization is particularly likely to receive social support from their colleagues. In the meantime, Ghadiri \& Beheshtifar (2015)[55] demonstrated a direct and significant relationship among OI, positive self-concept, and confidence of employees. Newman, Miao, Hofman and Zhu (2015)[56] proved that $\mathrm{OI}$ is the mediating role in human resource management and organizational citizenship behavior. Consequently, OI can be regarded as independent variable, mediating variable, or dependent variable, and it can be explored with organizational behavior or psychological function. In Taiwan, no studies have been conducted with teacher as the subject and OI as the variable, so this scale can be adopted by relative research.

\section{(II). Concerning Limitations and Future Directions}

In the past, OI was cut in from the angle of organizational culture or organizational commitment, but this research employs the viewpoint of workplace spirituality, aiming at exploration of spirituality. Additionally, the first sample batch in this research adopted Internet questionnaire that is difficult to control allocation of sampling. For example, Sample Background Allocation cannot be evenly distributed, and this is what the studies in the future should pay attention to. Finally, it is suggested that future study should set up norm for the answerers to learn their own relative position in the group.

\section{REFERENCES}

[1] M. R Edwards, R. Peccei, Perceived organizational support, 
organizational identification, and employee outcomes. Journal of Personnel Psychology, Vol: 9, No. 1, 2015. Retrieved from

http://econtent.hogrefe.com/doi/full/10.1027/1866-5888/a00 0007

[2] M. R. Edwards, R. Peccei, Organizational identification: Development and testing of a conceptually grounded measure. European Journal of Work and Organizational Psychology, Vol: 16, No. 1, 25-57, 2007.

[3] S. Boroş, P. L. Curşeu, M. Miclea, Integrative tests of a multidimensional model of organizational identification. Social Psychology, Vol: 42, No. 2, 111-123, 2015.

[4] B. Ashforth, S. Harrison, K. Corley, Identification in Organizations: An Examination of Four Fundamental Questions. Journal of Management, Vol: 34, No. 3, 325-374, 2008.

[5] C. R. Scott, S. R. Corman, G. Cheney, Development of a structurational model of identification in the organization. Communication Theory, Vol: 8, 298-336, 1998.

[6] A. Valackiene,. Theoretical model of employee social identification in organization managing crisis situations. Engineering Economics, Vol: 64, No. 4, 95-102, 2015.

[7] O. Christ, R. van Dick, U. Wagner, J. Stellmacher, When teachers go the extra mile: Foci of organisational identification as determinants of different forms of organisational citizenship behaviour among schoolteachers. British Journal of Educational Psychology, Vol: 73, 329-341, 2003.

[8] H. Tajfel, J. C. Turner, The social identity theory of intergroup behavior. In J. T. Jost \& J. Sidanius(Eds.), Political psychology: Key readings(pp. 276-293). New York, NY: Psychology Press, 2004.

[9] F. A .Mael, B. E. Ashforth, Alumni and their alma mater: A partial test of the reformulated model of organizational identification. Journal of Organizational Behavior, Vol: 13, 103-123,1992. Retrieved from http://onlinelibrary.wiley.co $\mathrm{m} / \mathrm{doi} / 10.1002 /$ job.4030130202/pdf

[10] A. Rego, M. P. e Cunha, Workplace spirituality and organizational commitment: An empirical study. Journal of Organizational Change Management, Vol: 21, No. 1, 53-75, 2008. Retrieved from

http://homepages.se.edu/cvonbergen/files/2013/01/Workplac e-Spirituality-and-Organizational-Commitment_An-Empiric al-Study.pdf

[11] Ashmos, D., \& Duchon, D. P.(2000). Spirituality at work: A conceptualization and measure. Journal of Management Inquiry, 9(2), 134-145. Retrieved from

http://ejournal.narotama.ac.id/files/ProQuest_54883215.pdf

[12] J. Milliman, A. J. Czaplewski, J. Ferguson, Workplace spirituality and employee work attitudes: A exploratory empirical assessment. Journal of Organizational Change Management, Vol: 16, No. 4, 426-447, 2003.

[13] V. Kinjerski, The Spirit at Work Scale: Developing and Validating a measure of individual spirituality at work. In J. Neal(Ed.), Handbook of faith and spirituality in the workplace(pp. 383-402). New York, NY: Springer, 2013.

[14] S. Shellenbarger, More relaxed boomers, fewer workplace frills and other job trends. Wall Street Journal, p. B-I, 2000.
[15] S. Krishnakumar, C. P. Neck, The "what", "why" and "how" of spirituality in the workplace. Journal of Managerial Psychology, Vol: 178, No. 3, 153-164, 2002 .

[16] J. C. Garcia- Zamor, Workplace spirituality and organizational performance. Public Administration Review, Vol: 63, No. 3, 355-363, 2003.

[17] D. H. Heaton, J. Schmidt-Wilk, F. Travis, Constructs, methods, and measures for researching spirituality in organizations. Journal of Organizational Change Management, Vol: 17, No. 1, 62-82, 2004.

[18] J. Claude, G. Zamor, Workplace spirituality and organizational performance. Public Administration Review, Vol: 63, No. 3, 355-363, 2003. Retrieved from http://onlinelibrary.wiley.com/doi/10.1111/1540-6210.00295 $/ \mathrm{pdf}$

[19] C. D. Pielstick, ,Teaching spiritual synchronicity in a business leadership class. Journal of Management Education, Vol: 29, No. 1, 158-159, 2005.

[20] M. Stevison, E. Dent, D. White, Toward a greater understanding of spirit at work: A model of spirit at work and outcomes. Paper presented at Academy of Management Proceedings of Academy of Management Annual Meeting, Chicago, IL, 2009.

[21] C. L. Jurkiewicz, R. A. Giacalone, A values framework for measuring the impact of workplace spirituality on organizational performance. Journal of Business Ethics, Vol:49, No. 2, 129-142, 2004.

[22] A. G. K. Abdullah, A. Ismail, Validating and standardization the Scale of Malay Version Workplace Spirituality from Malaysian school settings. International Journal of Asian Social Science, Vol: 3, No. 6, 1418-1430, 2013. Retrieved from

http://www.pakinsight.com/pdf-files/ijass\%203(6),\%201418 $-1430 . p d f$

[23] B. S. Pawar, Individual spirituality, workplace spirituality and work attitudes: An empirical test of direct and interaction effects. Leadership \& Organization Development Journal, Vol: 30, No. 8, 759-777, 2009.

[24] S. Piryaei, R. Zare, Workplace spirituality and positive work attitudes: The moderating role of individual spirituality. Indian Journal of Economics and Development, Vol: 1, No. 4, 91-97, 2013. Retrieved from http://indjst.org/index.php/ijed/article/view/33677/27762

[25] D. T .Duchon, A. Plowman, Nurturing the spirit at work: Impact on work unit performance. The Leadership Quarterly, Vol: 16, 807-833, 2005.

[26] L. T. Eby, D. M. Freeman, M. C. Rush, C. E. Lance, Motivational bases of affective organizational commitment: A partial test of an integrative theoretical model. Journal of Occupational and Organizational Psychology, Vol: 72, No. 4, 463-483, 1999.

[27] Y. Wiener, Commitment in organizations: A normative view. Academy of Management Review, Vol: 7, No. 3, 418-428, 1982.

[28] J. B.Vancouver, N. W. Schmitt, An exploratory examination of person - organization fit: Organizational goal congruence. Personnel Psychology, Vol: 44, No. 2, 333-352, 1991.

[29] J. E. Finegan, The impact of person and organizational values 
on organizational commitment. Journal of occupational and Organizational Psychology, Vol: 73, No. 2, 149-169, 2000.

[30] G .Hofstede, B.Neuijen, D. D. Ohayv, G. Sanders,. Measuring organizational cultures: A qualitative and quantitative study across twenty cases. Administrative Science Quarterly, Vol: 35, 286-316, 1990. Retrieved from http://web.a.ebscohost.com/ehost/pdfviewer/pdfviewer?sid= 360c1d59-dfbe-4f5e-bbf9-700d645f7778\%40sessionmgr400 $4 \&$ vid $=1 \&$ hid $=4204$

[31] L. Rhoades, R. Eisenberger, S. Armeli, Affective commitment to the organization: The contribution of perceived organizational support. Journal of Applied Psychology, Vol: 86, 825-836, 2001.

[32] D. R .Denison, What is the difference between organizational culture and organizational climate? A native's point of view on a decade of paradigm wars. Academy of Management Review, Vol: 21, 619-654, 1996.

[33] D. J. McAllister, G. A. Bigley, Work context and the definition of self: How organizational care influences organization-basei self-esteem. Academy of Management Journal, Vol: 45, No. 5, 894-904, 2002.

[34] D. G. Gardner, J. L. Pierce, Self-esteem and self-efficacy within the organizational context an empirical examination. Group \& Organization Management, Vol: 23, No. 1, 48-70, 1998.

[35] R. Van Dick, U. Wagner, J. Stellmacher, O. Christ, The utility of a broader conceptualization organizational iden $\neg$ tification. Which aspect really matter? Journal of Occupational and Organizational Psychology, Vol: 77, 171-191, 2004.

[36] K. Yildiz, Analysis of the relation of teachers' organizational identification and organizational communication. Education Sciences: Theory \& Practice, Vol: 13, No. 1, 264-272, 2013.

[37] J. McIver, E. G. Carmines,. Unidimensional scaling (Vol. 24). Beverly Hills, CA: Sage, 1981.

[38] H. F. Kaiser, The application of electronic computers to factor analysis. Educational and Psychological Measurement, Vol: 20, 141-151, 1960. doi: 10.1177/00131644600200011

[39] L. R. Fabrigar, D. T Wegener, R. C. MacCallum, E. J .Strahan, Evaluating the use of exploratory factor analysis in psychological research. Psychological methods, Vol: 4, No. 3, 272-299, 1999. Retrieved from

http://personal.psu.edu/jxb14/M554/articles/Fabrigaretal199 9.pdf

[40] R. B. Cattell, The scree test for the number of factors. Multivariate Behavioral Research, Vol: 2, No. 2, 245-276, 1996.

[41] J. L. Horn, A rationale and test for the number of factors in factor analysis. Psychometrika, Vol:30, 179-185, 1965 Retrieved from http://www.87994.com/read/e39c40070202015922dd263c.ht $\mathrm{ml}$

[42] B. G.Tabachnica, L. S. Fidell, Using multivariate statistics(4th ed.). Needham Heights, MA: Allyn and Bacon, 2007.
[43] J. C. Anderson, D. W. Gerbing, The effect of sampling error on convergence, improper solutions and goodness-of-fit indices for maximum likelihood confirmatory factor analysis. Psychometrika, Vol: 49, 155-173, 1984.

[44] J. F. Hair, R. E. Anderson, R. L. Tatham, W. C. Black, Multivariate data analysis(5th ed.). Upper Saddle River, NJ: Prentice Hall, 1998.

[45] K. A. Bollen, Structural equations with latent variables. New York, NY: Wiley \& Sons, 1989.

[46] R. P. Bagozzi, Y. Yi, On the evaluation of structural equation models. Journal of the Academic of Marketing Science, Vol: 16, 74-94, 1998. doi: 10.1007/BF02723327

[47] C. Fornell, D. F. Larcker, Evaluating structural equation models with unobservable variables and measurement error. Journal of marketing research, Vol: 18, 39-50, 1981. Retrieved from

http://web.b.ebscohost.com/ehost/pdfviewer/pdfviewer?sid= b760ebc7-bf82-46b3-a617-6492c0f44a63\%40sessionmgr1 1 $0 \&$ vid $=0 \&$ hid $=106$

[48] J. C. Anderson, D. W.Gerbing, Structural equation modeling in practice: A review and recommended two-step approach. Psychological bulletin, Vol: 103, No. 3, 411-423, 1998.

[49] B. Y. Huang, The working stress of teachers: A mata-analysis. Kaohsiung Normal University Journal, Vol: 38, 27-48, 2015.

[50] J. Cohen, Statistical power analysis for the behavioral sciences(2nd ed.). Hillsdale, NJ: Lawrence Erlbaum, 2013.

[51] B. Byrne, Burnout: Testing for the validity, replication, and invariance of causal structure across elementary, intermediate, and secondary teachers. American Educational Research Journal. Vol: 31, 645-673, 1994.

[52] I. A. Friedman, Student behaviour patterns contributing to teacher burnout. Journal of Educational Research, Vol: 88, No. 5, 281-289, 1995.

[53] M. Riketta, Organizational identification: A meta-analysis. Journal of Vocational Behavior, Vol: 66, No. 2, 358-384, 2005.

[54] L. Avanzi, S. C. Schuh, F. Fraccaroli, R. van Dick, Why does organizational identification relate to reduced employee burnout? The mediating influence of social support and collective efficacy. Work \& Stress, Vol: 29, No. 1, 1-10, 2015 .

[55] M. Ghadiri, M. Beheshtifar, Investigate the relationship between organizational identification and positive self-concept and confidence of employees. International Journal of Academic Research, Vol: 7, No. 1, 76-80, 2015.

[56] A. Newman, Q. Miao, P. S. Hofman, C. J. Zhu, The impact of socially responsible human resource management on employees' organizational citizenship behaviour: the mediating role of organizational identification. The International Journal of Human Resource Management, 1-16, 2015 . 